CUADERNOS DE ESTUDIOS GALLEGOS, LXVIII

Núm. 134 (enero-diciembre 2021), págs. 395-421

ISSN: $0210-847 \mathrm{X}$

https://doi.org/10.3989/ceg.2021.134.13

\title{
LAS EDICIONES DE EL LIBRO DE LOS ESTADOS EN LA HISTORIOGRAFÍA ESPAÑOLA DEL SIGLO XIX
}

\author{
Jose Ángel SALGAdo Loureiro \\ Universidad de Santiago de Compostela \\ ORCID iD: http://orcid.org//0000-0003-1526-4925
}

Copyright: (C) 2021 CSIC. La edición electrónica de esta revista se distribuye bajo los términos de una licencia de uso y distribución Creative Commons Reconocimiento 4.0 Internacional (CC BY 4.0).

Cómo citar/Citation: José Ángel Salgado Loureiro, "Las ediciones de El libro de los estados en la historiografía española del siglo XIX", Cuadernos de Estudios Gallegos, 68, núm. 134 (2021), págs. 395-421, https://doi.org/10.3989/ceg.2021.134.13 


\title{
LAS EDICIONES DE EL LIBRO DE LOS ESTADOS EN LA HISTORIOGRAFÍA ESPAÑOLA DEL SIGLO XIX
}

\begin{abstract}
RESUMEN
El libro de los estados (1327-1330) de don Juan Manuel es un texto castellano de contenido sociopolítico. El objetivo de este trabajo es analizar su consideración como objeto de estudio a través de sus dos primeras ediciones, realizadas ambas en 1860 por Antonio Benavides y por Pascual de Gayangos respectivamente. Partiendo del contexto de la historiografía española del siglo XIX, en el cual se consolidaron disciplinas como la historia y la historia de la literatura, veremos cómo el texto participa en el proceso de construcción de la identidad nacional. En el caso de Benavides, estudiaremos cómo su comprensión de El libro de los estados como texto histórico y de don Juan Manuel como personaje ilustre se insertan en un discurso conservador pro-monárquico. En lo que respecta a Gayangos veremos que reproduce una consideración generalizada del texto como un espejo de príncipes y de don Juan Manuel como autor didáctico, desprovista de connotaciones políticas.

Palabras ClaVe: El libro de los estados, don Juan Manuel, Antonio Benavides, Pascual de Gayangos, historiografía española, medievalismo español.
\end{abstract}

\section{AS EDICIÓNS DO LIBRO DOS ESTADOS NA HISTORIOGRAFÍA ESPAÑOLA DO SÉCULO XIX.}

\section{RESUMO}

O Libro de los estados (1327-1330) de don Juan Manuel é un texto castelán de contido sociopolítico. O obxectivo deste traballo é analizar a súa consideración como obxecto de estudo a través das súas dúas primeiras edicións, realizadas ambas en 1860 por Antonio Benavides e por Pascual de Gayangos respectivamente. Partindo do contexto da historiografía española do século XIX, no cal se consolidaron disciplinas como a historia e a historia da literatura, veremos o xeito no que o texto participa da construción da identidade nacional.

No caso de Benavides, estudaremos como a súa comprensión do Libro de los estados como texto histórico e de don Juan Manuel como personaxe ilustre se insiren nun discurso conservador pro-monárquico. No que respecta a Gayangos veremos que reproduce unha consideración xeralizada do texto como un espello de príncipes e de don Juan Manuel como autor didáctico, desprovista de connotacións políticas.

Palabras Clave: El libro de los estados, don Juan Manuel, Antonio Benavides, Pascual de Gayangos, historiografía española, medievalismo español.

\section{THE EDITIONS OF EL LIBRO DE LOS ESTADOS IN $19^{\mathrm{TH}}$ CENTURY SPANISH HISTORIOGRAPHY}

\section{ABSTRACT}

El libro de los estados (1327-1330) written by don Juan Manuel, is a Castilian text of sociopolitical content. The main objective of this essay is to analyse its significance as a subject of study by means of its first two editions, both of which were published in 1860 by Antonio Benavides, and Pascual de Gayangos respectively. On the basis of the context of $19^{\text {th }}$ century Spanish historiography, during the consolidation of disciplines such as history and history of literature, we will look into how the text participated in the construction process of the Spanish national identity.

With respect to Benavides, we will showcase how his understanding of El libro de los estados as a historical source and of don Juan Manuel as an illustrious character, both took part in a conservative discourse favouring monarchical power. Regarding Gayangos, we will see how he reproduced a widespread consideration of the text as a mirror for princes and of don Juan Manuel as a didactical writer, lacking any political meaning.

KeY WORDS: El libro de los estados, Don Juan Manuel, Antonio Benavides, Pascual de Gayangos, Spanish historiography, Spanish medievalism. 
Recibido/Received: 28/05/2020

Aceptado/Accepted: 11/10/2020

$E$ llibro de los estados es un texto medieval castellano de marcado contenido sociopolítico y compuesto en forma de diálogo didáctico por don Juan Manuel entre 1327 y 1330. Podemos considerar que el estudio crítico del texto se inició en la década de 1930 y fue ganando progresivo interés a lo largo del siglo XX, principalmente de mano del medievalismo y del hispanismo filológico. Ahora bien, el arranque de este interés hay que localizarlo algunas décadas antes, en torno al año 1860, cuando se inicia su proceso de edición con Antonio Benavides y Pascual de Gayangos.

En el presente trabajo analizaremos la consideración de El libro de los estados como objeto de estudio en el medievalismo español del siglo XIX, centrándonos en las referidas ediciones de Benavides y de Gayangos. De igual modo, hacemos notar que la comprensión del texto como objeto de estudio estuvo condicionada por la consideración que ha recibido don Juan Manuel. Es por ello que, junto con el tratamiento del texto, estudiaremos también el uso de la figura del autor como pieza del discurso historiográfico decimonónico español.

Comenzaremos con una aproximación al contexto historiográfico en el que se editó El libro de los estados. Tras ello, tanto en el caso de Benavides como en el de Gayangos observaremos su posicionamiento dentro de este contexto. A partir de ahí podremos analizar las implicaciones de sus respectivas comprensiones sobre El libro de los estados y don Juan Manuel.

\section{EL LIBRO DE LOS ESTADOS EN EL CONTEXTO DE LA HISTORIOGRAFÍA ESPAÑOLA DEL SIGLO XIX}

Todas las ediciones de El libro de los estados de las que disponemos han sido realizadas sobre la base que ofrece el ms. 6376 de la Biblioteca Nacional ${ }^{1}$. En el

\footnotetext{
${ }^{1}$ Una descripción del contenido y características del ms. 6376, así como su filiación con los demás manuscritos en los que se conservan textos de don Juan Manuel completos o fragmentarios puede verse: Fernando Gómez Redondo y José Manuel Lucía Megías, “Juan Manuel”, en José Manuel Lucía Mejías y Carlos Alvar Esquerra (eds.), Diccionario filológico de literatura medieval española textos y transmisión,
} 
siglo XIX se aprecia un interés crítico creciente sobre este manuscrito, siendo el único testimonio medieval en el que se conservan casi todas las obras de don Juan Manuel. A inicios de la centuria no sólo no existían ediciones de todas estas obras, sino que tampoco había un consenso claro sobre su número total, su datación o mismo su nomenclatura. Lo que sí existía era una consideración de don Juan Manuel como un personaje destacado, extraída principalmente sobre las referencias que se hacen a su figura en las crónicas castellanas de los siglos XIII y XIV, así como sobre la amplia difusión que desde época temprana había recibido El libro del conde Lucanor. Frente a esto, en el presente trabajo nos centraremos, como se ha indicado, en las ediciones decimonónicas de El libro de los estados realizadas por Antonio Benavides y Pascual de Gayangos. Cabría notar, eso sí, que no se trató de ediciones críticas, sino de simples transcripciones del texto contenido en el ms. 6376.

La primera edición crítica del texto no fue publicada hasta 1974, de mano de los hispanistas Robert Brian Tate e Ian R. Macpherson, trabajo que sería revisado y vuelto a publicar en 1991, actualizando el estudio crítico². En 1968, José María Castro y Calvo había publicado también una nueva transcripción del ms. $6376^{3}$. También José Manuel Blecua lo había incluido en su edición de las Obras completas de don Juan Manuel en 19824. En 2004, José Luis Villacañas Berlanga transcribió también el texto sobre el ms. 6376 en la Biblioteca Saavedra Fajardo de Pensamiento Político Español ${ }^{5}$. En 2007, Carlos Alvar y Sarah Finci publicaron la última edición de las Obras completas hasta la fecha, que en 2014 fue digitalizada en el marco del Proyecto Parnaseo ${ }^{6}$. No obstante, de entre todas las ediciones existentes, el trabajo de Robert Brian Tate e Ian R. Macpherson sigue presentando el estudio crítico más exhaustivo y completo sobre El libro de los estados.

\footnotetext{
Madrid, Castalia, 2000, págs. 718-724. El manuscrito digitalizado está disponible en la Biblioteca Digital Hispánica: Don Juan MANuel, Obras, Biblioteca Digital Hispánica [en línea], disponible en <http://bdh. bne.es/bnesearch/detalle/bdh0000012961> [Consulta: 10/01/2020].

2 Don Juan Manuel, El Libro de los estados, ed. de Robert Brian Tate e Ian R. Macpherson, Oxford, Claredon, 1974 y Don Juan Manuel, El Libro de los estados, ed. de Robert Brian Tate e Ian R. Macpherson, Madrid, Castalia, 1991.

3 Don Juan Manuel, Libro de los Estados, ed. de José María Castro y Calvo, Barcelona, Universidad de Barcelona, 1968.

4 Don Juan Manuel, Obras completas, t. I, ed. de José Manuel Blecua, Madrid, Gredos, 1982.

5 Don Juan Manuel, Libro de los estados, ed. de José Luís Villacañas Berlanga, Biblioteca Saavedra Fajardo de Pensamiento Político Español, 2004 [en línea], disponible en <http://www.saavedrafajardo. org/Archivos/LIBROS/Libro0171.pdf> [Consulta: 12/05/2020].

${ }^{6}$ Don Juan Manuel, Obras completas, ed. de Carlos Alvar y Sarah Finci, Madrid, Biblioteca Castro, 2007 y Don Juan Manuel, Obras completas, eds. Carlos Alvar y Sarah Finci, Monografias Aula Medieval, 3 (2014) [en línea], disponible en <http://parnaseo.uv.es/AulaMedieval/AulaMedieval.php?id=Libro DeLosEstados\&id2=ant\#monografias $>$ [Consulta: 12/05/2020].
} 
Al igual que sucedió en otros países europeos, hacia mediados del siglo XIX asistimos en España a un proceso de progresiva institucionalización de la historia como disciplina académica ${ }^{7}$. Este fenómeno afectó también a la historia de la literatura, que a partir de la década de 1820 fue adquiriendo mayor representatividad en la reglamentación académica española ${ }^{8}$. El auge de este tipo de disciplinas se explica por el papel que jugaron dentro del panorama político y social español. Los estudios históricos no se orientaron tanto a la investigación en sí como a la función de educar a los ciudadanos en los valores de la política liberal, revirtiendo un marcado tono ilustrativo y ejemplificante.

La cronología de los editores que tomamos como caso de estudio nos sitúa en un periodo concreto, que fue el reinado de Isabel II. A tal efecto, estudiosos como Sanmartín Bastida ${ }^{9}$ o López Serrano ${ }^{10}$ han utilizado el concepto de historiografía isabelina como marco para definir el discurso histórico nacionalista liberal del momento. En su aplicación al medievalismo, este discurso parece haberse desarrollado mayormente conforme a planteamientos políticos y sociales de tipo moderado y conservador. Dentro de este contexto, tanto la historia como la historia de la literatura funcionaron con una utilidad práctica nacionalizadora. Se generaron relatos acerca del patrimonio cultural básico sobre el que se iban configurando la autoconciencia y la identidad nacional española ${ }^{11}$.

Ha de tenerse en cuenta que "no existió unanimidad a la hora de presentar el pasado único de la nación" ${ }^{12}$, sino que cada relato histórico e histórico-literario

\footnotetext{
7 Ignacio PeIRó MARTín, "La historiografía académica en la España del siglo XIX", Memoria y civilización: anuario de historia, 1 (1998), pág. 166.

8 Santiago PÉREZ ISASI, "La historiografía literaria como herramienta de nacionalización en España (1833-1939)", Oihenart, 25 (2010), pág. 269.

9 En el caso de la profesora Rebeca Sanmartín Bastida, en el año 2000 constituyó parte del marco para el estudio de "La concepción de la historia" del medievalismo decimonónico español en su tesis doctoral. Véase: Rebeca SANMARTín BASTIDA, La Edad Media y su presencia en la literatura, el arte y el pensamiento españoles entre 1860 y 1890, Madrid, Universidad Complutense de Madrid, 2000, págs. 48-56. Para el uso del concepto de historiografia isabelina en este contexto véase la página 50.

${ }^{10}$ En el caso más reciente de Francisco de Asís López Serrano, la historiografía isabelina es el contexto general en el que situó su investigación predoctoral sobre el político e historiador Modesto Lafuente, contemporáneo de Antonio Benavides y Pascual de Gayangos. Véase: Francisco de Asís LóPEz SERrano, De los origenes a Pelayo. Modesto Lafuente en su contexto historiográfico, Málaga, Universidad de Málaga, 2013.

11 Tomamos como ilustrativa la definición de López Serrano, que comprendió que la historiografía isabelina "responde a esas nuevas necesidades estatales y que adquiere una relevancia esencial como soporte textual de una doctrina que tiene como objeto y sujeto a la nación española. El nuevo Estado requiere de un soporte cultural, de un pasado común, de unos signos distintivos y la historia actuará como catalizador de la memoria colectiva”. Véase: LóPez SERrano, De los orígenes a Pelayo..., pág. 186. De igual modo, consideramos oportuno llamar la atención sobre los trabajos de Santiago Pérez Isasi, que también incluye a la historia de la literatura dentro como instrumento de nacionalización en el siglo XIX español. Sobre ello se puede ver: PÉREZ ISASI, "La historiografía literaria...”, págs. 267-279.

12 López Serrano, De los orígenes a Pelayo..., pág. 164.
} 
se expone desde diferentes perspectivas, a veces contradictorias en algunos puntos. Ahora bien, todos ellos se construyen sobre un grupo más o menos definido de valores positivos idealmente considerados como españoles. Algunos de estos serían el honor, la lealtad, la religiosidad católica, la caballerosidad y el alto sentido de la dignidad ${ }^{13}$. A ellos se sumaría el orientalismo, el componente islámico característico del medievo hispano, aunque se trata de un elemento controvertido que tomó carices muy dispares, positivos o negativos. En los relatos resultantes se pueden apreciar, en mayor o menor medida, usos políticos del discurso histórico que se adaptan a las necesidades y preferencias ideológicas del historiador. No sólo se buscan en la Edad Media las raíces de la esencia nacional, sino que se manipula el pasado para idealizar y demandar los valores conforme a los que se ha de regir el presente ${ }^{14}$.

Dentro de este contexto, la figura de don Juan Manuel y sus obras integraron una parte destacada del patrimonio identitario nacional. En lo que se refiere al caso concreto de El libro de los estados, no disponemos de una referencia completa de las transcripciones del texto realizadas durante el siglo XIX. No obstante, algunos indicios parecen apuntar a que habría despertado cierto interés entre los eruditos españoles del momento. Nos referimos aquí a la posible circulación de copias, totales o parciales, de las que se conserva algún testimonio. Véase, por ejemplo, el ms. 5960 de la Biblioteca Nacional, que contiene una copia de la primera parte de El libro de los estados en ciento ochenta y cuatro folios en papel ${ }^{15}$. De igual modo, en 1981 José Manuel Blecua puso en duda que Pascual de Gayangos hubiese consultado el ms. 6376, "sino las copias del XIX, que quizá fuesen algunas encargo suyo"16. Efectivamente, entre las obras que pertenecieron a Gayangos y que fueron adquiridas por la Biblioteca Nacional tras su defunción se encuentra el ms. 17978, un texto del XIX que contiene las

\footnotetext{
${ }_{13}$ Pérez Isasi estudió cómo desde las historias de la literatura española se configuran dos tendencias historiográficas que juegan con este conjunto de valores. Una "reducida" que parte de la identificación sistemática de elementos como la lengua, la nación y el estado para situar el origen literario de la nación en el castellano medieval. Frente a ello estaría la tendencia "amplia", que incluye otros idiomas peninsulares y comprende diferentes puntos de origen de la nación. Véase: Santiago PéREZ IsASI, "El nacimiento de la nación en las historias de la literatura española del siglo XIX", en Vicente Montserrat Cots y Antonio Monegal (coords.), Actas del XVII Simposio de la Sociedad Española de Literatura General y Comparada, t. I, Barcelona, Universitat Pompeu Fabra-Sociedad Española de Literatura General y Comparada, 2010, págs. 299-307.

${ }^{14}$ Sobre esto llamamos la atención sobre el punto de "el uso político del medievalismo. La recepción de la historia" dentro de su investigación doctoral: SANMARTín BASTIDA, La Edad Media y su presencia..., págs. 150-167.

15 El manuscrito digitalizado está disponible en la Biblioteca Digital Hispánica: Don Juan MANUEL, Libro de los estados. Parte primera, Biblioteca Digital Hispánica [en línea], disponible en <http://bdh.bne.es/ bnesearch/detalle/bdh0000173522> [Consulta: 10/02/2020].

${ }^{16}$ Sobre ello véase el aparato crítico a su edición de las Obras completas de don Juan Manuel: Don JUAN Manuel, Obras completas, t. I, ed. de José Manuel Blecua, Madrid, Gredos, pág. 23.
} 
Obras del Infante D. Juan Manuel ${ }^{17}$ y que seguramente sería la copia del ms. 6376 sobre la que trabajó.

\section{El DisCURSo POlítico DE ANTONIO BENAVIDES DESDE EL RELATO HISTÓRICO SOBRE FERNANDO IV}

La transcripción de El libro de los estados realizada por Antonio Benavides se incluyó dentro de su monográfico Memorias del rey D. Fernando IV con el objetivo de ilustrar el relato sobre el mandato de este rey ${ }^{18}$. De igual modo, recurrió al texto en su calidad de fuente para reconstruir la vida de don Juan Manuel y su contexto histórico. En base a esto podemos ver que se le otorga una consideración de objeto de estudio histórico y no de simple obra literaria. Debemos tener en cuenta que la disponibilidad de ediciones de textos medievales todavía era bastante limitada, lo que condicionaba su conocimiento. Así, el hecho de incluir obras como El libro de los estados en su monográfico servía tanto para ilustrar como para justificar las afirmaciones que de él se extraían.

Visto esto, para comprender el uso que hizo Benavides de El libro de los estados y de la figura de don Juan Manuel es necesario comprender el sentido global con el que compuso Memorias del rey D. Fernando IV. Con tal fin atenderemos a algunos rasgos de su doble faceta como político e historiador. A la altura del año 1860 gozaba ya de una sólida trayectoria en ambos aspectos ${ }^{19}$. En 1826 fue nombrado doctor en Leyes por la Universidad de Granada a los diecinueve años y catedrático de la Novísima Recopilación de las Leyes de España ${ }^{20}$ en 1827. En

\footnotetext{
17 En el Catálogo de los manuscritos que pertenecieron a D. Pascual de Gayangos aparece referido como “n. 869”. Véase: Pedro RocA y LóPEZ, Catálogo de los manuscritos que pertenecieron a D. Pascual de Gayangos existentes hoy en la Biblioteca Nacional, Madrid, Tip. de la Revista de Archivos, Bibliotecas y Museos, 1904, pág. 290. El texto digitalizado se puede consultar en la Biblioteca Digital Hispánica: Don Juan Manuel, Obras del Infante D. Juan Manuel, Biblioteca Digital Hispánica [en línea], disponible en <http://bdh.bne.es/bnesearch/detalle/bdh0000133848> [Consulta: 10/02/2020]. La pertenencia a Gayngos se puede confirmar por la presencia de su sello personal, que Álvarez Millán describe como "un sello cuadrangular y oblongo en tinta roja dentro de cuyo simplicísimo marco se lee: «D. Pascual de Gayangos». Véase: Cristina Álvarez Millán, “A propósito de dos cartas enviadas a la Real Academia de la Historia: Pascual de Gayangos (1809-1897) y el patrimonio bibliográfico español”, Pliegos de Bibliofilia, 24 (2003), pág. 72.

18 Antonio Benavides, Memorias del rey D. Fernando IV, t. I, Madrid, Real Academia de la Historia, 1860, págs. 444-499.

19 Para una síntesis de su trayectoria política e intelectual se puede consultar el perfil biográfico que Juan Soto Climent da de este autor en el portal web de la Real Academia de la Historia. Véase: Juan Soto Climent, "Antonio Benavides y Fernández de Navarrete”, Diccionario Biográfico Español, Real Academia de la Historia [en línea], disponible en <http://dbe.rah.es/biografias/13619/antonio-benavidesy-fernandez-de-navarrete ${ }^{-3}$ [Consulta: 30/08/2019]. De igual modo, se puede consultar el perfil biográfico que se incluye en: Gonzalo Pasamar Alzuria e Ignacio Peiró Martín, Diccionario Akal de historiadores españoles contemporáneos (1840-1980), Madrid, Akal, 2002, págs. 120-121.

${ }^{20}$ La Novísima Recopilación de las Leyes de España fue una recopilación de leyes publicada en 1805
} 
1830 ingresó en la Real Academia de la Historia, de la cual fue director entre 1862 y 1888 . A partir de 1857 fue miembro fundador de la Real Academia de Ciencias Morales y Políticas.

Entre 1831 y 1864 ocupó diversos cargos políticos dentro del partido moderado, de corte monárquico-constitucional. Desde 1844 fue uno de los principales miembros de la facción de este partido conocida como los puritanos ${ }^{21}$. La posición ideológica de los puritanos como grupo dentro de los moderados es un elemento a tener muy en cuenta para comprender el sentido en el que se componen las Memorias del rey $D$. Fernando $I V$. De forma sintética podemos apuntar que, como han señalado algunos autores, la Constitución de 1845 fue el mejor reflejo de la ideología moderada, apostando por un sistema de soberanía compartida entre el rey y las élites sociales que se manifestaban a través de las Cortes $^{22}$. Dentro de esto, los puritanos destacaron por su carácter más conservador y marcadamente pro-monárquico en detrimento del poder de las Cortes.

De forma general se puede situar a Benavides entre los políticos e intelectuales decimonónicos que promovían la renovación de la historiografía española a nivel teórico e ideológico ${ }^{23}$. Su dedicación a la historia política y militar, especialmente a la historia de los reyes ${ }^{24}$, lo sitúa como ejemplo de la tendencia historiográfica dominante a mediados del siglo XIX, que se centraba en los grandes personajes y eventos nacionales. De entrada, el objetivo de sus publicaciones no es otro que el de ilustrar la historia de España. Ahora bien, en trabajos como

en la que se revisaba y actualizaba el obsoleto código jurídico vigente hasta el momento, datado de finales del siglo XVII. El texto original se puede consultar a través de una versión digitalizada a cargo del Boletín Oficial del Estado. Agencia Estatal Boletín Oficial del Estado, "Novísima Recopilación de las Leyes de España", Biblioteca Jurídica Digital [en línea], disponible en <https://www.boe. es/publicaciones/biblioteca_juridica/publicacion.php?id=PUB-LH-1993-63_NOV\%C3\%8DSIMA_ RECOPILACI\%C3\%93N_DE_LAS_LEYES_DE_ESPA\%C3\%91A\&tipo=L\&modo=1> [Consulta: 30/08/2019].

${ }^{21}$ Sobre la ideología política de Benavides y su trayectoria dentro del partido moderado se pueden ver: José Luis Comellas, Los moderados en el poder 1844-1854, Madrid, Escuela de Historia Moderna, 1970, págs. 242-251 y págs. 322-326; Pasamar Alzuria y Peiró Martín, Diccionario Akal..., pág. 121.

${ }^{22}$ Sobre esto puede verse: María del Carmen GARcía-NieTo, Javier María DonÉzAR y Luis LóPez PuERTA, Moderados y progresistas, 1833-1868, Madrid, Guadiana, 1971, págs. 26-28; Comellas, Los moderados..., págs. 142-150 y págs. 195-199.

23 Pasamar Alzuria y Peiró Martín, Diccionario Akal..., pág. 120.

${ }^{24}$ En 1852 había publicado una "Memoria sobre la guerra de Granada y los textos y conciertos que precedieron a las capitulaciones de la ciudad" y, entre 1852 y 1854, vieron la luz los tres tomos de su Compendio histórico filosófico de todas las monarquías, con la biografía de todos los reyes y príncipes reinantes hasta el día: obra ilustrada con los retratos de cuerpo entero de todos los reyes, reinas y príncipes herederos. Véanse: Antonio BENAVIDEs, "Memoria sobre la guerra de Granada y los textos y conciertos que precedieron a las capitulaciones de la ciudad", Memorias de la Real Academia de la Historia, VIII (1852); Compendio histórico filosófico de todas las monarquías, con la biografia de todos los reyes y príncipes reinantes hasta el día: obra ilustrada con los retratos de cuerpo entero de todos los reyes, reinas y príncipes herederos, Madrid, M. Rivadeneyra, 1852-1854, 3 vols. 
Memorias del rey D. Fernando IV, "el juicio moral que se da a los acontecimientos tiene un cierto eco de referencia al presente"25. A través del sentido políticomoralizante que imprime a su escritura, se establecen paralelismos para mostrar las lecciones que permitan mejorar la sociedad en la que vive.

Aludiendo al tópico de la función ilustrativa de la historia, al inicio de las $\mathrm{Me}$ morias del rey $D$. Fernando $I V$ se puede leer que "pocos períodos de más útiles enseñanzas presenta la historia de nuestra patria que el corrido desde el año de 1295 hasta el de $1312 "$ "26. Sobre ello, cabe destacar que dos de los elementos más representativos del reinado de Fernando IV fueron, por un lado, la conflictividad interna ${ }^{27} \mathrm{y}$, por el otro, la alta frecuencia en la celebración de cortes ${ }^{28}$. Bajo esta premisa, Benavides encontró argumentos para caracterizar este reinado como un periodo de debilidad de la institución regia, acuciada por los enfrentamientos entre los diferentes agentes de la política castellana (nobleza, Iglesia y concejos urbanos) entre finales del siglo XIII e inicios del siglo XIV ${ }^{29}$. Este periodo de debilidad se mantendría hasta el restablecimiento de la estabilidad y el orden político y social con Alfonso $\mathrm{XI}^{30}$.

En la aplicación de esta perspectiva por parte de Benavides se puede ver el reflejo de una consideración ideológicamente negativa sobre la participación de las élites sociales en la política. De este modo, la utilidad de la enseñanza que se puede extraer de este periodo histórico sería, grosso modo, que en ausencia de un poder monárquico fuerte no podría existir avance o mejora alguna para la sociedad y la Corona de España.

El USO EJEMPLARIZANTE DE EL LIBRO DE LOS ESTADOS COMO ESPEJO DE LA SOCIEDAD POR ANTONIO BENAVIDES

Como se ha indicado más arriba, Antonio Benavides recurrió a El libro de los estados como fuente histórica. En base a él completó la reconstrucción de la vida

\footnotetext{
25 SAnMartín Bastida, La Edad Media y su presencia..., pág. 164.

26 Benavides, Memorias del rey..., pág. i.

27 César González Mínguez, "Fernando IV de Castilla (1295-1312) perfil de un reinado", Espacio, tiempo y forma. Serie III, Historia medieval, 17 (2004), págs. 223-244.

28 Guillermo SANTAMARÍA ToRQuEMADA, "La legislación en cortes sobre la cancillería de Fernando IV: 1295-1312”, en Las Cortes de Castilla y León 1188-1988: actas de la tercera etapa del Congreso Científico sobre la Historia de las Cortes de Castilla y León, t. I, Valladolid, Simancas-Cortes de Castilla y León, 1990, pág. 285.

29 Sobre esto, Sanmartín Bastida opinó que Benavides es un defensor de la figura de Fernando IV, véase: SAnMARTín BAstidA, La Edad Media y su presencia..., pág. 163. Frente a ello, podemos considerar que, efectivamente, es un defensor de la institución monárquica pero no precisamente de la figura de este rey, mayormente representado como débil.

${ }^{30}$ Benavides, Memorias del rey..., págs. i-iii.
} 
y el pensamiento de don Juan Manuel, así como el contexto de las ideas políticas y sociales de la Castilla de los siglos XIII y XIV. Para ello, el gran volumen de contenido sociopolítico del texto lo convirtió en un elemento de notable valor histórico a la altura de otras fuentes como las crónicas. Este uso del texto para conocer al autor y a su sociedad revierte en ambos casos un alto valor ejemplificante y alegórico.

Dentro de este uso se puede leer una comprensión de El libro de los estados como fuente para el conocimiento de la sociedad castellana del siglo XIV, así como de la historia de los códigos legales y morales de España, comparándolo con las Siete Partidas de Alfonso X.

Pero ¿qué más? el mismo D. Juan Manuel, coetáneo de D. Alonso, ¿no escribió varias obras en las que resplandecen la más pura moral, y los principios salvadores y cristianos de la piedad, de la mansedumbre, de la lealtad y de la hidalguía? ${ }^{31}$.

Se establece así una equivalencia en la que el texto de don Juan Manuel es, en lo político-moral, lo que el código alfonsí en lo jurídico-político.

El libro de los estados adquiere un valor doctrinal que sirve para prefigurar una serie de virtudes que deben poseer los súbditos de la Corona y que benefician al conjunto de la nación. Cuestiones como la moralidad, la fe, la lealtad, la nobleza, la templanza o la moderación se presentan como cualidades ausentes en el presente de Benavides y que deberían observarse para corregir los desvíos y desórdenes de la sociedad y la política españolas.

El libro de los Estados, que puede considerarse como una gráfica pintura de aquel siglo, adorna con tales virtudes al emperador, al rey, al príncipe, á los infantes y á los caballeros, que más que hombres de tiempos pasados parecen hombres del siglo actual, por su templanza, su moderación y otras prendas tan recomendables para gobernar los reinos en estos tiempos, en los cuales ha desaparecido la fé de los subditos, y solo se atiende á la conveniencia y á la razón individual, producto de la mas ilimitada discusión sobre todas las instituciones humanas ${ }^{32}$.

\footnotetext{
31 Benavides, Memorias del rey..., pág. 334.

32 Benavides, Memorias del rey..., págs. 334-335.
} 
Este tipo de afirmaciones sitúan a Benavides dentro del medievalismo conservador del XIX, desde el cual se postula un retorno a la armonía de las fórmulas político-sociales del pasado y los valores tradicionales ${ }^{33}$.

Las páginas dedicadas a relatar la biografía de don Juan Manuel constituyen una de las secciones de las Memorias del rey D. Fernando IV en las que Benavides reseña la vida de algunos personajes ilustres de la Corona de Castilla ${ }^{34}$. Aquí, El libro de los estados sirve para constatar la alta talla política y moral atribuida a don Juan Manuel como figura esencial para comprender la realidad histórica castellana. Se establece así un modelo, un espejo al que deberían mirarse los políticos españoles del XIX. Sobre su persona se prefiguran algunas capacidades y virtudes morales como la valentía, la fortaleza, la constancia o la proactividad.

\begin{abstract}
Todo lo que hemos entresacado del libro de los Estados corrobora y dá fuerza á lo que hemos aventurado acerca de las creencias, opiniones y carácter de D. Juan Manuel. Si la suerte le hubiese favorecido hasta el punto de colocarle en el trono de Castilla, pocos reyes le hubieran igualado, ninguno excedido. Valiente en la batalla, entendido en la guerra, político en la paz, conocedor de los hombres, enérgico, firme, constante, apenas le faltaba una prenda de las que tanto se necesitan para llevar una corona; pero ya que la suerte no le fué muy favorable por no hallarse á la altura que demandaban su vasta ciencia y su esclarecido ingenio, ya que no para sí, supo preparar y disponer tronos para su descendencia ${ }^{35}$.
\end{abstract}

Otro elemento propio del imaginario nacionalista decimonónico que Benavides exalta en don Juan Manuel es el profundo catolicismo que imprimió a su escritura. Para ello se recurre de nuevo a El libro de los estados, entendiendo el fervor religioso como una virtud político-moral. Don Juan Manuel aparece representado como un "celoso defensor de la religión católica, como demuestran sus escritos, y muy particularmente el libro de los Estados"36. A tal efecto, Benavides transcribe el capítulo sesenta del texto afirmando que:

(...) no es otra cosa mas que una enseñanza de la mas pura y ortodoxa doctrina católica: y en varios parajes de la misma obra

\footnotetext{
${ }_{33}$ Sobre estos rasgos del medievalismo español de corte conservador en el siglo XIX véase: SANMARTíN BASTIDA, La Edad Media y su presencia..., págs. 150-154.

${ }^{34}$ Otros personajes y textos se incluyen en la sección de Memorias del rey D. Fernando IV denominada como "Ilustraciones”. Véase: BenAVIDES, Memorias del rey..., págs. 245-696.

35 Benavides, Memorias del rey..., pág. 351.

${ }^{36}$ Benavides, Memorias del rey..., pág. 346.
} 
se encuentran multiplicados ejemplos de cuán afirmadas estaban en el corazón del autor las creencias de aquella época de guerra entre dos razas rivales, opuestas en religión, costumbres y sistema social ${ }^{37}$.

En esto se puede apreciar, también, una consideración negativa del componente musulmán de los reinos hispánicos. El elemento oriental se comprende como la antítesis de la esencia católica sobre la que se forja el espíritu medieval español reflejado en El libro de los estados.

En vista de todo lo anterior, podemos ver que el valor de El libro de los estados como texto histórico se vio reforzado por el uso tropológico de la historia generando discursos con fines políticos. Sirvió así para ilustrar conceptos considerados positivos, como la fe o los atributos nobles de los hombres de gobierno. Como se ha indicado más arriba, la intención discursiva global de Memorias del rey $D$. Fernando $I V$ parece haber sido defender el poder de la monarquía frente a las cortes. Para ello se habría servido de las lecciones sociopolíticas de El libro de los estados, ratificadas por la alta talla política y moral de don Juan Manuel. Sin embargo, una lectura más atenta del texto muestra una imagen del poder regio opuesta a la defendida por Benavides. Don Juan Manuel parece presentar un poder limitado por el de otros agentes de la política castellana, como fueron los ricohombres de finales del siglo XIII e inicios del XIV ${ }^{38}$. Sobre ello hemos de notar que el trabajo de Benavides no implicaría un estudio real y pormenorizado del contenido de El libro de los estados como fuente. Más bien parece haber realizado una lectura simple y acrítica con el fin de respaldar un relato histórico altamente ideologizado.

\section{PASCUAL DE GAYANGOS Y LA VOLUNTAD DE RENOVACIÓN HISTORIOGRÁFICA DEL MEDIEVALISMO ESPAÑOL}

La transcripción de El libro de los estados realizada por Pascual de Gayangos se incluye, con el resto de las obras de don Juan Manuel, en el último de los tres volúmenes que publicó en la colección de la Biblioteca de Autores Españoles de Manuel Rivadeneyra en 1860, bajo el título de Escritores en prosa anteriores al siglo $X V$. Los dos volúmenes anteriores, publicados en 1857 y en 1858, se habían dedicado respectivamente a Libros de caballerías y a La gran conquista

\footnotetext{
37 Benavides, Memorias del rey..., pág. 347.

${ }^{38}$ José Ángel Salgado Loureiro, "El rey molinista pensado por don Juan Manuel en El libro de los estados”, História Revista, 24, 2 (2019), págs. 84-102.
} 
de Ultramar ${ }^{39}$. El volumen en el que se incluye la obra de don Juan Manuel está dedicado a textos castellanos catalogados como literatura didáctica, como serían el Calila e Dimna, los Castigos y documentos de Sancho IV, El libro de los exemplos, El libro de los gatos y El libro de las consolaciones de la vida humana.

Tal y como señaló López Estrada, la principal virtud de la participación de Gayangos en la Biblioteca de Autores Españoles fue la de introducir la temática medieval en esta colección que, hasta el momento, se había centrado en la publicación de textos del Siglo de Oro en adelante. De igual modo, en lo que se refiere concretamente a don Juan Manuel, se centró en reivindicar su posición destacada en la historia de la literatura medieval española como autor de prosa didáctica ${ }^{40}$.

Ahora bien, es preciso tener en cuenta que la prosa castellana no parece haber sido el principal objeto de trabajo de Gayangos o, al menos, no su preferido. Siendo un personaje altamente polifacético destacó en varios planos de la intelectualidad del momento, principalmente como bibliófilo, archivista y editor. A pesar de su afición a los libros de caballerías y a la cronística medieval, su atención se centró sobre todo en la recuperación, estudio y difusión de los textos árabes de época medieval. Su gran empeño en este último aspecto ha llevado a que se lo considere como el padre de la escuela de arabistas modernos españoles ${ }^{41}$.

Tanto su formación como su actividad se desarrollaron entre Francia, España e Inglaterra ${ }^{42}$. La edición de las obras de don Juan Manuel, entre las que se incluye El libro de los estados, se llevó a cabo en la etapa posterior a su regreso de Londres en 1843. En 1837, el desencanto académico y profesional, junto con la turbulenta situación de la política española, lo habían empujado a trasladarse a Reino Unido, lugar de origen de su esposa y en donde preveía mejores prospectivas personales. Sería allí donde habría de consolidarse definitivamente como intelectual de talla internacional. Durante su estancia en Londres se relacionó y colaboró con otros autores de renombre europeos y estadounidenses, como

\footnotetext{
39 Pascual de Gayangos, Libros de caballerías, con un discurso preliminar y un catálogo razonado, Madrid, M. Rivadeneyra, 1857 (Biblioteca de Autores Españoles, 40); La gran conquista de ultramar, que mandó escribir el rey don Alfonso el Sabio: Ilustrada con notas críticas y un glosario, Madrid, M. Rivadeneyra, 1858 (Biblioteca de Autores Españoles, 44); Escritores en prosa anteriores al siglo XV, Madrid, M. Rivadeneyra, 1860 (Biblioteca de Autores Españoles, 51).

${ }^{40}$ Francisco LóPEz Estrada, "Pascual de Gayangos y la literatura medieval castellana", Alfinge: revista de filología, 4 (1986), págs. 21-22 y pág. 27.

${ }^{41}$ Sobre esto pueden verse las consideraciones de Velasco de Castro y de López Estrada: Rocío VelasCo DE CASTRO, “Arabismo y colonialismo español: Pascual de Gayangos y la cuestión marroquí", Norba: Revista de Historia, 22 (2009), pág. 250; LóPez Estrada, "Pascual de Gayangos...”, pág. 12.

42 Pasamar Alzuria y Peiró Martín, Diccionario Akal..., págs. 293-294.
} 
Georges Ticknor o William H. Prescott, dedicándose a cuestiones no siempre relacionadas con el arabismo ${ }^{43}$.

Antes de su traslado a Inglaterra había ocupado diferentes cargos públicos, como el de oficial de Hacienda en 1830, o el de oficial de segunda de interpretación de lenguas del Ministerio de Estado en 1833. En 1836 ejerció también como profesor de Lengua Árabe en el Ateneo de Madrid de forma gratuita. Este tipo de funciones se alternaron $y$, en algunos casos, se abandonaron en favor de su pasión por la indagación en los archivos españoles y marroquíes para encontrar, indexar, copiar o adquirir manuscritos. En algunos casos, estas tareas se vieron facilitadas por la obtención de diferentes comisionados oficiales con tal objeti$\mathrm{vo}^{44}$.

Más allá de su función como arabista, la importancia de Gayangos como historiador no se puede apreciar del todo atendiendo sólo a sus publicaciones. Hay que considerar su labor de forma global, atendiendo a sus actividades en pro de la conservación y difusión de textos medievales. Así, a su protagonismo en el "rescate de los documentos que servirían para construir la historia nacional" 45 se sumaría la edición de fuentes con el objetivo de hacerlas accesibles a otros investigadores ${ }^{46}$.

También ha de tenerse en cuenta su papel como colaborador, no siempre reconocido, aportando materiales para diversos estudios históricos y literarios de otras personas. De este modo, permaneció en "un discreto segundo plano" con respecto a la construcción de la historia medieval de España en el siglo XIX, aportando la base sobre la que amigos y discípulos llevaron a cabo sus investigaciones ulteriores ${ }^{47}$. Así, podemos situar a Pascual de Gayangos dentro de la tupida y heterogénea red de eruditos e incipientes académicos del momento dedicados a "moldear la conciencia histórica de los españoles"48.

En vista de lo anterior, para comprender el tratamiento que Gayangos dispensa a El libro de los estados y a don Juan Manuel en Escritores en prosa anterio-

\footnotetext{
43 Pedro Roca y LóPez, "Noticia de la vida y obras de don Pascual de Gayangos. II. Gayangos en Inglaterra”, Revista de Archivos, Bibliotecas y Museos, Tercera época, 2 (1898), págs. 13-32.

${ }^{44}$ Sobre la vida Pascual de Gayangos hasta 1837 se puede ver el trabajo de su discípulo, Pedro Roca: Pedro Roca y López, "Noticia de la vida y obras de don Pascual de Gayangos. I. Juventud de Gayangos", Revista de Archivos, Bibliotecas y Museos, Tercera época, 1 (1897), págs. 544-565. En lo que se refiere a la labor archivística y bibliófila de Gayangos en Marruecos, véase el estudio de Rocío Velasco: Velasco DE CAstro, “Arabismo y colonialismo español...”, págs. 245-262.

${ }^{45}$ Cristina Álvarez Millán, "Pascual de Gayangos y la Historia Medieval de España”, Espacio, Tiempo y Forma, Serie III, 17 (2004), pág. 43.

46 López Estrada, "Pascual de Gayangos...", págs. 21-22.

47 Santiago SantiÑo Ramírez De Alda, "Pascual de Gayangos y Arce: una vida para la historia", Andalucia en la historia, 64 (2019), pág. 76.

48 Peiró Martín, "La historiografía académica...”, pág. 167.
} 
res al siglo $X V$, es necesario comprender su postura ante las tendencias historiográficas del medievalismo español del XIX. De entrada, en su trabajo no parece entreverse una intencionalidad política tan evidente como en el caso de Antonio Benavides. No obstante, sí que se puede apreciar una perspectiva historiográfica determinada. Así, por ejemplo, Velasco de Castro destacó las implicaciones de su labor de indagación y recopilación en los archivos marroquís en relación con la política colonial española en el norte de África y con la existencia de una corriente "maurófila" entre algunos de los arabistas españoles del momento ${ }^{49}$.

Tanto las indagaciones en archivos y bibliotecas como el estudio y la edición de textos hispanoárabes por parte de Pascual de Gayangos estuvieron impulsados, en parte, por lo que parece haber sido un deseo de revisionismo historiográfico. La voluntad de integrar el elemento musulmán como algo positivo en la construcción del pasado medieval de la nación, supuso un estímulo en el ambiente cultural español que algunos percibieron como divergente. Con ello, Gayangos buscaba desplazar algunos tópicos heredados de la historiografía precedente para mejorar la imagen que se proyectaba de España hacia el exterior ${ }^{50}$. Así, por ejemplo, los dos tomos de su History of the Mohammedan dynasties, publicados entre 1840 y 1843 durante su estancia en Londres, se concibieron bajo la idea de que la traducción literal de las obras árabes para su posterior comparación con las crónicas castellanas sería "la única manera de hacer algún progreso serio" "51. En tal sentido podemos suscribir la opinión de López Estrada al considerar a Gayangos como "un crítico romántico (...), por generación y por temperamento, en forma moderada, pero de una manera auténtica"52.

Como se ha indicado más arriba, fue después de este periodo, a su retorno de Londres, cuando Gayangos se dedicó a publicar ediciones de textos castellanos. Para comprender mejor su posicionamiento con respecto al medievalismo español en estos momentos puede resultar de utilidad atender a su posicionamiento político. A pesar de haberse criado en un ambiente familiar de ideología liberal progresista y con tradición militar, no fue un militante especialmente activo y mantuvo una actitud escéptica con respecto a las convulsiones que azotaban la política y la sociedad españolas del siglo XIX.

\footnotetext{
49 Velasco de CASTRO, “Arabismo y colonialismo español...”, págs. 248-249.

${ }^{50}$ Sobre el aspecto revulsivo de la integración del mundo musulmán en la historia de España resulta de especial interés el trabajo de Velasco: VELASCO DE CASTRO, “Arabismo y colonialismo español...", pág. 260. Para el carácter subversivo de Gayangos con respecto al ambiente intelectual del momento se puede ver el trabajo de Santiño Ramírez: SANTIÑo Ramírez de AldA, "Pascual de Gayangos y Arce...”, pág. 74. ${ }^{51}$ M. Manzanares de CirRe, "Don Pascual de Gayangos (1809-1897) y los estudios árabes", Al-Andalus: revista de las escuelas de estudios árabes de Madrid y Granada, 28, 2 (1963), pág. 451.

${ }^{52}$ López Estrada, "Pascual de Gayangos...”, pág. 24.
} 
De forma general se ha asentado cierta consideración sobre la aparente asepsia política de Gayangos. Esta idea se puede rastrear hasta los trabajos biográficos de su discípulo Pedro Roca, quien lo presentó como hombre que no era "de aficiones políticas ni de inclinaciones belicosas" 53 . Si bien esto podría aplicarse a la primera parte de su vida, con el paso del tiempo parece haber ganado mayor implicación en la política española. Militó en el Partido Liberal Fusionista de Sagasta y fue Senador del Reino por la provincia de Huelva y por la Real Academia de la Historia en diversos periodos entre 1881 y $1894^{54}$. Además, participó en la fundación de la Asociación Española para la Exploración de África en 1877 y fue miembro de la Sociedad Española de Africanistas y Colonialistas ${ }^{55}$.

A través de la correspondencia epistolar que mantuvo durante su estancia en Londres se puede apreciar un tipo de patriotismo sincero, pero crítico y algo laxo. El cinismo con el que se refiere a la situación convulsa de España ha llevado a que se le atribuyese un "tono un tanto antipatriótico" "56. No obstante, leídas con algo más de atención, se aprecia cómo con el paso de los años refleja cierta nostalgia y manifiesta deseos de volver a su tierra de origen. Tal y como apuntó Álvarez Millán, "lo cierto es que en estas cartas reverbera una voz que ansía volver a su patria y se oye el desesperado eco de un "de lo contrario, si no se dan prisa, Vds. se lo pierden"57.

\footnotetext{
53 Véase: Roca y LóPez, "Noticia de la vida y obras de don Pascual de Gayangos. II...”, págs. 22-26.

54 Pasamar Alzuria y Peiró Martín, Diccionario Akal..., pág. 294.

55 Velasco de CASTRo, “Arabismo y colonialismo español...”, págs. 259-260.

56 Manzanares de Cirre, "Don Pascual de Gayangos...”, págs. 446-447. Parte de esta correspondencia se puede ver en las publicaciones biográficas sobre Pascual Gayangos elaboradas por uno de sus discípulos, Pedro Roca. Sobre el "tono antipatriótico" destacamos una carta de abril de 1383: “(...) si se dicen y escriben por ahí muchos disparates respecto á nuestro desgraciado país y, por último, si no te escriben tus amigos llenándote las cartas de amonestaciones, consejos y tantáleas esperanzas, poniéndote delante de los ojos mil mejoras y ventajas en que antes no pensabas, tratando por todos los medios posibles de excitar tu apagado ó adormecido amor patriae. A mí me escribe uno lo siguiente: No seas tonto, chico, déjate de ingleses y de comer rosbify plunpudin y vente aquí, que ahora es el momento de que todos los jóvenes de talento acudan á recoger laureles (¿si lo dirá por equivocación en lugar de porrazos, multas y prisiones?) y á arrimar como buen patriota el hombro para la consolidación del Gobierno presente y de la libertad". En el mismo sentido se puede ver también otra carta de septiembre de 1838: "Querido Santiago (...) Supongo que por más que te escriban de allí que todo va muy bien, no te irás á meter otra vez en las fauces del lobo, hacer centinela, correr á las armas, hablar de política, fumar el cigarrillo y maldecir á la Francia ó á la Inglaterra, causa única de nuestros males, porque si á los españoles los dejasen solos”. Véase: RocA Y LÓPEZ, "Noticia de la vida y obras de don Pascual de Gayangos. II...”, págs. 21-22.

57 Álvarez Millán, “A propósito de dos cartas...”, pág. 4. Al año siguiente de publicar este trabajo, Álvarez Millán incluyó una carta de julio de 1841 en "Pascual de Gayangos y la Historia Medieval de España", en la cual no sólo se aprecian síntomas de patriotismo, sino un indicio de anhelo por volver a España: "por estas razones, y porque estoy harto de Inglaterra e Ingleses, que quiero hablar y escribir en castellano y que deseo ante todas las cosas que mis hijos sean Españoles y se eduquen como tales, estoy pensando, concluido que haya lo que tengo entre manos, el cambiar el roast-beef y plumpudding por el arrocillo y otros comistrajos de esa tierra". Véase: Álvarez Millán, "Pascual de Gayangos...”, pág. 48.
} 
La labor secundaria de Pascual de Gayangos como historiador a través de sus contribuciones y de la edición de textos también sirvió para construir una memoria medieval de España que justificase un presente determinado. Cuando Álvarez Millán hizo hincapié en su papel como colaborador aportando materiales para los estudios históricos de terceros, mencionaba su participación "en la Comisión de Cortes y Fueros, destinada a recopilar todo tipo de textos y noticias sobre antiguas Cortes de los reinos hispánicos, fueros municipales y cartaspuebla", cuyo objetivo era el de "ilustrar los orígenes legales de las instituciones del Nuevo Régimen constitucional" 58 . La recepción, organización y edición de los textos recuperados quedó a cargo del por entonces bibliotecario de la Real Academia Tomás Muñoz y Romero, quien destacó como historiador y jurista siendo un precursor de la historia de las instituciones en España. El resultado fue la publicación de ejemplares como la Colección de fueros municipales y cartas pueblas por la Real Academia de la Historia. Catálogo, en 1852 y la Colección de Cortes de los antiguos Reinos de España por la Real Academia de la Historia. Catálogo, en $1855^{59}$. Su estudio del régimen foral se enfocó hacia el objetivo de conocer la historia y "la índole de las costumbres" de un país que desde la Edad Media habría excedido al resto de Europa en "la perfección de su estado social y político" ${ }^{60}$. Vemos así que Gayangos no se desvía totalmente de las tendencias de su época. Mantiene cuestiones como el carácter ilustrativo de la historia y su puesta al servicio de una determinada comprensión de la sociedad y la política españolas.

De igual modo, se aprecia en Gayangos cierto gusto por los personajes ilustres de la nación a través de los materiales que recompiló, pero que parecen no haber fructificado en publicación alguna. Entre estos se pueden destacar algunos como los Apuntes de D. Pascual de Gayangos para un Diccionario biográfico y bibliográfico de españoles ilustres, que se conservan en los fondos de la Biblioteca Nacional de España ${ }^{61}$. En un intento por sistematizar la que habría sido la biblioteca de Pascual de Gayangos, que en su mayoría se encuentra repartida entre la Biblioteca Nacional y la Real Academia de la Historia, Escribano Martín informa también de la existencia de unas Apuntaciones biográficas, en forma

\footnotetext{
58 Álvarez Millán, "Pascual de Gayangos...”, pág. 42.

59 Sobre estas publicaciones informa también Álvarez Millán, véase: Álvarez Millán, "Pascual de Gayangos...”, pág. 44, nota 22.

${ }^{60}$ Tomás MuÑoz y Romero (ed.), Colección de fueros municipales y cartas pueblas de los reinos de Castilla, León, Corona de Aragón y Navarra, Madrid, Impág. de José María Alonso, 1847, pág. 3.

${ }^{61}$ La ficha del manuscrito se puede consultar en El portal de datos bibliográficos de la Biblioteca Nacional de España: BiBlioteca NACiOnAl De España, “Apuntes de D. Pascual de Gayangos para un Diccionario biográfico y bibliográfico de españoles ilustres”, El portal de datos bibliográficos de la Biblioteca Nacional de España [en línea], disponible en <http://datos.bne.es/edicion/a5527948.html> [Consulta: $15 / 04 / 2020]$.
} 
de Diccionario, de personajes históricos, sacadas de las crónicas de Alfonso XI, Pedro I, Enrique II y III y Juan I"2. Sobre ello apuntó que "desde un punto de vista histórico e historiográfico el material que recopiló Gayangos puede ser importantísimo y seguramente no sea tan conocido como debiera"63.

\section{Pascual de Gayangos y las obras de don JuAn MANuEl Dentro de la HISTORIA DE LA PROSA DIDÁCTICA MEDIEVAL CASTELLANA}

Como se ha indicado más arriba, Gayangos publicó su edición de las obras de don Juan Manuel en 1860, esto es, en la etapa posterior a su regreso desde Londres. Durante este periodo se aprecia un mayor interés por las letras castellanas en detrimento de su dedicación a "las letras árabes", que había sido más intensa "en los primeros años de su vida que en los posteriores"64. Cabe notar que, cuando publicó Escritores en prosa anteriores al siglo $X V$ no solo ya había publicado otros dos tomos dentro de la Biblioteca de Autores Españoles, sino que en 1851 había publicado, también con Manuel Rivadeneyra, una traducción al castellano de la Historia de la literatura española de su amigo Georges Ticknor ${ }^{65}$.

En vista de su perspectiva historiográfica, así como de su trayectoria académica y profesional, parece claro que su intención con este tipo de publicaciones fue principalmente la de difundir fuentes para fomentar nuevos temas y perspectivas de estudio. En el caso concreto de El libro de los estados, y parece que de forma extensiva al resto de obras de don Juan Manuel, no se perciben implicaciones político-historiográficas en el tratamiento del texto ni del autor. De igual modo, las introducciones que preceden a los textos incluidos dentro de Escritores en prosa anteriores al siglo $X V$ tienden al sintetismo, especialmente si se las compara con las de los tomos anteriores que publicó en la Biblioteca de Autores Españoles sobre los libros de caballería y sobre La gran conquista de ultramar ${ }^{66}$.

\footnotetext{
${ }^{62}$ Fernando Escribano Martín, "Pascual de Gayangos, descubridor de pasados olvidados viajeros. La sistematización de una biblioteca”, Isimu: Revista sobre Oriente Próximo y Egipto en la Antigüedad, 10 (2007), pág. 103.

${ }^{63}$ Escribano Martín, "Pascual de Gayangos, descubridor...”, pág. 103.

${ }^{64}$ Manzanares de CirRe, "Don Pascual de Gayangos ...”, pág. 449.

${ }^{65}$ M. Georges Ticknor, Historia de la Literatura Española, vol. I, trad. de Pascual de Gayangos y Enrique de Vedia, Madrid, M. Rivadeneira, 1851. En relación a esta publicación, se ha destacado que Gayangos no sólo proporcionó a Georges Ticknor materiales para su composición, sino que introdujo nuevas anotaciones originales sobre la literatura árabe en su traducción. Sobre esto pueden verse: ÁlvAREZ MiLLÁN, "Pascual de Gayangos...”, pág. 39; LóPez EstradA, "Pascual de Gayangos...”, págs. 18-21.

${ }^{66}$ Sobre este aspecto ya incidió en su momento López Estrada, véase: LóPEz EsTRADA, "Pascual de Gayangos...", pág. 26. Efectivamente, en Libros de caballerías, sólo los prólogos, el "discurso preliminar" y el "catálogo razonado de los libros de caballerías que hay en lengua castellana o portuguesa, hasta el año de 1800" ocupan una extensión de noventa y dos páginas, véase: GAYANGOS, Libros de caballerías..., págs. i-xcii. En La gran conquista de ultramar, la introducción dedicada exclusivamente a esta obra
} 
En lo que se refiere a la consideración de El libro de los estados como objeto de estudio, Gayangos le reconoció cierto valor histórico en base a su contenido sociopolítico y autobiográfico al igual que hizo también Benavides. No obstante, no profundizó en estas cuestiones más allá de la simple mención, ya que su comprensión del texto fue la de una obra esencialmente didáctico-literaria, siendo esta una consideración que sigue primando hoy en día. ${ }^{67}$ En lo tocante al valor histórico que deriva de su contenido sociopolítico, lo consideró, junto con El libro infinido, como un texto de literatura didáctico-política perteneciente al género de los espejos de príncipes. Estas obras serían, así, un reflejo de las costumbres y el pensamiento de la nobleza castellana de inicios del XIV sobre su propia realidad sociopolítica ${ }^{68}$.

\begin{abstract}
Bajo una forma sencillísima, no son más que un enchiridion ó manual para uso déla nobleza de aquellos tiempos, un código cortesano en qué se definen y fijan las obligaciones mutuas entre reyes y vasallos, y se establecen reglas para la crianza, educación y conducta de nobles y señores; un libro, en fin, de regimiento de príncipes así para la vida pública como para la privada ${ }^{69}$.
\end{abstract}

Resulta llamativo que omitiese El libro del caballero y del escudero dentro de esta categoría sin dar una explicación concreta para ello.

Anteriormente se ha presentado la voluntad de revisionismo historiográfico de Pascual de Gayangos a partir de los textos árabes. Aquí se puede observar una pauta similar, aunque de forma tenue y puntual, sobre la potencialidad de El libro de los estados como fuente para el estudio de la biografía de don Juan Manuel. Se observa, así, que El libro de los estados contiene "circunstancias y coincidencias que bien merecen ser mencionadas, porque acaso tengan relación con sucesos de su propia vida que nos son desconocidos"70. Pese a ser don Juan Manuel uno de los personajes más influyentes de su época, la información que

\footnotetext{
se extiende por dieciséis páginas, véase: Gayangos, La gran conquista de ultramar.., págs. i-xvi. Sin embargo, todas las obras recogidas en Escritores en prosa anteriores al siglo $X V$ comparten un total de veintidós páginas de aparato introductorio, véase: GAYANGOS, Escritores en prosa..., págs. i-xxii.

${ }^{67}$ Sobre ello se puede ver la comprensión desligada en el monográfico coordinado por María Jesús Lacarra en su monográfico de 2014, en el que el capítulo dedicado a El libro de los estados, a cargo de Fernando Gómez Redondo: María Jesús LACARRA, "Don Juan Manuel (1282-1348): orgullo nobiliario y escritura", Monografías Aula Medieval, 2 (2014) [en línea], págs. 5-15 y Fernando Gómez RedonDO, "El libro de los estados", Monografias Aula Medieval, 2 (2014) [en línea], págs. 45-66, disponible en $<$ http://parnaseo.uv.es/AulaMedieval/AulaMedieval.php?id=monografias\#monografias $>$ [Consulta: $12 / 05 / 2020]$.

68 Gayangos, Escritores en prosa..., pág. xviii.

${ }^{69}$ Gayangos, Escritores en prosa..., pág. xix.

70 Gayangos, Escritores en prosa..., pág. xix.
} 
se tenía sobre él era escasa y, en ocasiones, contradictoria. Gayangos atribuyó gran parte de este desconocimiento a que sus obras no habrían sido leídas con la debida atención. De lo contrario se podrían extraer datos importantes que aportó sobre sí mismo, valiosos para la reconstrucción de un periodo histórico, posicionándose a la altura de otras fuentes como las cronísticas.

Siendo las noticias que de él tenemos a la vez vagas y contradictorias, por no haberse aun leido con la debida atención las obras en que él mismo dejó consignados importantes sucesos de su vida politica y privada, y tratándose como se trata de uno de nuestros más célebres escritores, no estará de más el que con ayuda de tan preciosos materiales, y los que nos suministran además las Crónicas de Fernando IV y Alfonso XI, intentemos bosquejar la vida del hombre que más influyó en la literatura castellana durante el siglo $X I V^{71}$.

La comprensión de El libro de los estados como un objeto de estudio de carácter principalmente literario por parte de Gayangos está supeditada a la propia comprensión de don Juan Manuel. Éste aparece representado como uno de los personajes ilustres del medievo español, suponiendo un punto culminante en el desarrollo de la prosa didáctica medieval como continuador de la labor cultural de Alfonso X el Sabio ${ }^{72}$. En este planteamiento recogió y difundió una imagen generalizada en el momento que ya estaba presente en obras anteriores, como la que había traducido de Georges Ticknor ${ }^{73}$. No obstante, cabría puntualizar que Gayangos profundizó y rectificó algunas cuestiones planteadas por Ticknor quien, por ejemplo, consideraba perdidas varias de las obras de don Juan Manuel entre las que se encontraría "su obra sobre los diferentes estados de los hombres" $" 74$.

La comprensión didáctico-literaria de don Juan Manuel vinculada a Alfonso $\mathrm{X}$ estuvo presente también en la Historia crítica de la literatura española de Amador de los Ríos. Esta obra de profundidad crítica sin precedentes hasta el momento fue publicada en 1863, fruto de una labor de veintiocho años. Siendo

\footnotetext{
71 Gayangos, Escritores en prosa..., pág. vii.

72 “(...) como literato bien podremos decir de él que, después de su tío don Alfonso el Sabio, nadie influyó tanto en el progreso de las letras castellanas”. Véase: GAYANGOS, Escritores en prosa..., pág. xix.

${ }^{73}$ Para consideración general de Georges Ticknor sobre don Juan Manuel véase: TicKNOR, Historia de la Literatura Española..., págs. 60-81. Las historias de la literatura como la elaborada por Ticknor son ejemplos de obras ampliamente aprovechadas para los nuevos estudios histórico-literarios que se estaban institucionalizando, a pesar de no haber sido concebidas como manuales. Sobre esto véase: PÉREZ ISASI, "La historiografía literaria...", pág. 272.

${ }^{74}$ TicKNOR, Historia de la Literatura Española..., pág. 74.
} 
sólo tres años posterior a Escritores en prosa anteriores al siglo $X V$, pasó a convertirse en un trabajo de referencia dentro y fuera de España ${ }^{75}$. La coincidencia entre los planteamientos generales de Gayangos y Amador de los Ríos sobre don Juan Manuel parece confirmar que la posición recogida por el primero era, efectivamente, una consideración común entre los críticos del momento. De igual modo, una comparativa con la obra de Amador de los Ríos permite apreciar la notable neutralidad política de los planteamientos de Gayangos.

Como se ha indicado, la historia de la literatura jugó un papel esencial en el proceso de formación de una identidad nacional. Aunque Amador de los Ríos no destacó por desarrollar narraciones exaltadas para mover los ánimos del público en un sentido u otro, tampoco ocultó su ideología conservadora, católica y monárquica, siendo abiertamente partidario de Isabel $\mathrm{II}^{76}$. En el prólogo del primer tomo de la Historia crítica de la literatura española se aprecia su comprensión de la historia de la literatura como medio para conocer y difundir el patrimonio histórico-cultural de la nación ${ }^{77}$. Ya en el tomo cuarto se aprecian algunas consideraciones sobre El libro de los estados y sobre don Juan Manuel que se aproximan a los planteamientos de Antonio Benavides. Don Juan Manuel vuelve a aparecer como un personaje ejemplar que acumula virtudes políticas, militares, morales e intelectuales, llegando a suponer un modelo de respeto hacia la autoridad regia ${ }^{78}$. En cuanto a El libro de los estados, se incluiría dentro del conjunto de "obras literarias" que:

\section{(...) teniendo por base y fundamento la sociedad del siglo XIV (...) ofrecen un interés altamente histórico”, imprescindible para “comprender la constitución del pueblo español en aquellos días ${ }^{79}$.}

En vista de lo anterior se puede afirmar que Pascual de Gayangos contribuyó a asentar una concepción de don Juan Manuel como autor de obras didácticas y como personaje destacado en una comprensión casi episódica de la historia de

\footnotetext{
75 José María Ocaña Vergara, “Amador de los Ríos entre dos centenarios”, Boletín de la Real Academia de Córdoba, de Ciencias, Bellas Letras y Nobles Artes, 48, 99 (1978), págs. 82-86.

76 Juan Gómez CRESPO, "José Amador de los Ríos en el panorama cultural del siglo XIX”, Boletín de la Real Academia de Córdoba, de Ciencias, Bellas Letras y Nobles Artes, 48, 99 (1978), págs. 31-39.

77 José Amador DE Los Ríos, Historia crítica de la literatura española, t. I, Madrid, Imprenta de don José Rodríguez, 1861, páginas sin numeración.

78 José Amador DE Los Ríos, Historia crítica de la literatura española, t. IV, Madrid, Imprenta de don José Rodríguez, 1863, págs. 205-229. Resulta especialmente ilustrativo el pasaje de la página 229 en el que se afirma que don Juan Manuel habría destacado por su "estricta moral", no habiendo en sus escritos "amengüe ó menoscabo de la autoridad del trono ni del monarca que le hacía tan cruda guerra, cuando eran escritas la mayor parte de aquellas obras entre los sobresaltos de un asedio, ó entre las privaciones y fatigas de un campamento".

${ }^{79}$ Ríos, Historia crítica de la literatura española, t. IV, ..., pág. 243.
} 
la literatura española. Esta imagen preconcebida de don Juan Manuel explica el bajo nivel de crítica con el que leyó su vida y su obra, aún a pesar de la voluntad de revisionismo historiográfico que mostró en otros temas. Ahora bien, lejos de constituir una falla en el trabajo de Gayangos, el tratamiento general que dispensa tanto al autor como a sus obras parece confirmar que su intención habría sido simplemente la de hacer los textos accesibles al público. Es por ello que transcribió casi literalmente el contenido del ms. 6376 sin destilar ningún tipo de discurso con significación política ni social.

La consecuencia de este enfoque sobre el caso concreto de El libro de los estados fue que, como se ha indicado, Pascual de Gayangos se limitó a localizarlo como ejemplo del modelo textual de los regimientos de príncipes castellanos. En vista de su predilección y de su gran conocimiento sobre los textos árabes medievales, llama la atención el hecho de que no prestase mayor atención a su relación con la textualidad oriental a través de su filiación con el Barlaam y Josafat. Esta última fue una obra de la que don Juan Manuel extrajo el marco narrativo de El libro de los estados y que tuvo una amplia difusión en aquel contexto, por lo que seguramente la habría conocido.

De forma general podemos suponer que, bajo la perspectiva de Gayangos, $E l$ libro de los estados formaría parte del patrimonio cultural sobre el que se construía la memoria medieval de la nación y que debía ser revisada. Esta revisión habría de llevarse a cabo, por un lado, a la luz de las aportaciones de los textos árabes y, por el otro, sobre la lectura más atenta de los propios textos en castellano. Para finalizar cabría tener en cuenta que lo que podemos extraer acerca de la consideración de Pascual de Gayangos sobre El libro de los estados y sobre don Juan Manuel se basa mayormente en lo que conservamos de su trabajo. Habría sido de gran interés que se hubiese materializado alguno de los proyectos que no llegó a finalizar. López Estrada, por ejemplo, hizo referencia a un proyecto tentativo de Gayangos y Estébanez Calderón para elaborar su propia Historia de la literatura $^{80}$. De haber fructificado esta colaboración, las consideraciones de tipo histórico aquí contenidas podrían, o no, arrojar nuevos datos que modificasen la hipótesis que planteamos.

\section{CONCLUSIONES}

El arranque de las ediciones de El libro de los estados a mediados del siglo XIX lo sitúa en el contexto de una historiografía altamente politizada, orientada a la delimitación y reproducción de valores nacionales y nacionalizadores. Es

${ }^{80}$ LÓPeZ Estrada, “Pascual de Gayangos...”, pág. 18. 
posible que el interés que despertó aquí El libro de los estados se debiese principalmente a su amplio contenido sociopolítico. Esto lo habría convertido en un instrumento útil para generar discursos históricos conservadores, en los que se justifican o se demandan las condiciones y los principios que deberían regir la realidad política y social de la España del momento.

Como se ha visto hasta aquí, los trabajos de Antonio Benavides y de Pascual de Gayangos destacaron, en primer lugar, por ser las primeras ediciones del texto que se pusieron a disposición del público general. Ahora bien, las posturas de las que parten son de naturaleza diferente, provocando distintas comprensiones del texto como objeto de estudio y diferentes usos dentro del relato de cada uno.

La obra de Antonio Benavides está construida desde una postura ideológica entre moderada y conservadora. En ella se observa una consideración de El libro de los estados como texto histórico, que está estrechamente ligada a la idealización de don Juan Manuel como personaje ilustre y modelo de hombre político. A partir de ahí, el amplio volumen de temática sociopolítica que contiene el texto lo convirtió en una herramienta de gran utilidad para construir e ilustrar el discurso pro-monárquico de Benavides.

Este tipo de uso de El libro de los estados parece haber implicado un nivel bastante bajo de estudio crítico, acaso porque no interesaba o no era útil de cara a los objetivos de Antonio Benavides. Así pues, si bien de entrada presenta una comprensión del texto como fuente histórica, el uso que hizo del mismo muestra que funcionó como una herramienta ideológica.

El caso de Pascual de Gayangos es abiertamente diferente, ya que no parece entreverse una intencionalidad política en el relato histórico que construye sobre don Juan Manuel y El libro de los estados. Como se ha indicado, las implicaciones político-historiográficas que se podrían extraer de su trabajo se centrarían, sobre todo, en la apuesta por la inclusión del pasado musulmán en la historia medieval de España. Aunque apunta el potencial de El libro de los estados como fuente histórica, no lo desarrolla debido a que no es ese su propósito. Al contrario, su objetivo parece ser el de contribuir a la difusión de los textos medievales para así estimular la renovación del medievalismo español del XIX.

Lo que sí se puede apreciar en Gayangos es una comprensión preconcebida de El libro de los estados como objeto de estudio. Sin negar u omitir la importancia de su valor histórico y su contenido sociopolítico, reduce su comprensión a la de un texto didáctico. Se trata de una consideración aplicada de forma general a toda la obra de don Juan Manuel, homogeneizándola bajo esta etiqueta del didactismo. Pascual de Gayangos se localizó entre los primeros autores que recogieron y asentaron una comprensión literaria de las obras de don Juan Manuel bajo un enfoque filológico de estudio. De hecho, se trata de una comprensión que, con ligeras variaciones, parece ser la dominante aún hoy en día. 
El estudio únicamente de las ediciones de Benavides y de Gayangos podría llevarnos a la conclusión errónea de que el uso político de la figura de don Juan Manuel y de El libro de los estados se realizó sólo desde la historia, y no desde la historia de la literatura. No obstante, la introducción de la comparativa con Amador de los Ríos parece apuntar en sentido contrario. Por un lado, nos ha permitido confirmar la asepsia política de Gayangos. Por el otro, ha mostrado en Amador de los Ríos un doble uso del texto similar al de Benavides, como fuente histórica y como herramienta ideológica. Debemos tener en cuenta que se trató de una práctica bastante extendida en la historiografía del momento, aunque aplicada principalmente en el estudio de fuentes cronísticas y jurídico-políticas. Así, el empleo de El libro de los estados como recurso en el discurso histórico desde perspectivas políticas conservadoras se habría dado desde ambas disciplinas, historia y literatura, pero de forma puntual.

De igual modo, podemos notar que desde la historia de la literatura también se nota un uso político ideológico de la figura de don Juan Manuel. Ahora bien, un estudio más completo de este aspecto implicaría analizar, por un lado, la comprensión de todas las obras de don Juan Manuel como objeto de estudio y, por el otro, la consideración de su figura a través de las diferentes historias de la literatura española que se utilizaron y compusieron en el siglo XIX.

\section{BIBLIOGRAFÍA}

Álvarez Millán, Cristina, "A propósito de dos cartas enviadas a la Real Academia de la Historia: Pascual de Gayangos (1809-1897) y el patrimonio bibliográfico español”, Pliegos de Bibliofilia, 24 (2003), págs. 3-32.

Álvarez Millán, Cristina, "Pascual de Gayangos y la Historia Medieval de España", Espacio, Tiempo y Forma, Serie III, 17 (2004), págs. 37-52.

Álvarez Ramos, Miguel Ángel, "Un curioso testimonio acerca del rescate documental protagonizado por Pascual de Gayangos", RAM: Revista de la Asociación de Archiveros de la Comunidad de Madrid, 5 (2011), págs.148-165.

Benavides, Antonio, "Memoria sobre la guerra de Granada y los textos y conciertos que precedieron a las capitulaciones de la ciudad", Memorias de la Real Academia de la Historia, VIII (1852), págs. 3-53.

Benavides, Antonio, Memorias del rey D. Fernando IV, t. I, Madrid, Real Academia de la Historia, 1860.

Benavides, Antonio, Reyes contemporáneos. Compendio histórico filosófico de todas las monarquías, con la biografía de todos los reyes y príncipes reinantes hasta el día: obra ilustrada con los retratos de cuerpo entero de todos los reyes, reinas y príncipes herederos, Madrid, M. Rivadeneyra, 1852-1854, 3 vols.

Biblioteca Nacional de España, "Apuntes de D. Pascual de Gayangos para un Diccionario biográfico y bibliográfico de españoles ilustres”, El portal de datos bibliográficos de la 
Biblioteca Nacional de España [en línea], disponible en <http://datos.bne.es/edicion/ a5527948.html> [Consulta: 15/04/2020].

Comellas, José Luis, Los moderados en el poder 1844-1854, Madrid, Escuela de Historia Moderna, 1970.

Don Juan Manuel, Libro de los estados, ed. de José Luís Villacañas Berlanga, Biblioteca Saavedra Fajardo de Pensamiento Político Español, 2004 [en línea], disponible en $<$ http:// www.saavedrafajardo.org/Archivos/LIBROS/Libro0171.pdf> [Consulta: 12/05/2020].

Don Juan Manuel, Libro de los Estados, ed. de José María Castro y Calvo, Barcelona, Universidad de Barcelona, 1968.

Don Juan Manuel, Libro de los estados. Parte primera, Biblioteca Digital Hispánica [en línea], disponible en <http://bdh.bne.es/bnesearch/detalle/bdh0000173522> [Consulta: $10 / 02 / 2020]$.

Don Juan Manuel, Obras completas, ed. de Carlos Alvar y Sarah Finci, Madrid, Biblioteca Castro, 2007.

Don Juan Manuel, Obras completas, eds. Carlos Alvar y Sarah Finci, Monografias Aula Medieval, 3 (2014) [en línea], disponible en $<$ http://parnaseo.uv.es/AulaMedieval/AulaMedieval.php?id=LibroDeLosEstados\&id2=ant\#monografias $>$ [Consulta: 12/05/2020].

Don Juan Manuel, Obras completas, t. I, ed. de José Manuel Blecua, Madrid, Gredos, 1981.

Don Juan Manuel, Obras del Infante D. Juan Manuel, Biblioteca Digital Hispánica [en línea], disponible en <http://bdh.bne.es/bnesearch/detalle/bdh0000133848> [Consulta: 10/02/2020].

Don Juan Manuel, Obras, Biblioteca Digital Hispánica [en línea], disponible en $<$ http://bdh. bne.es/bnesearch/detalle/bdh0000012961> [Consulta: 10/01/2020].

Escribano Martín, Fernando, "Pascual de Gayangos, descubridor de pasados olvidados viajeros. La sistematización de una biblioteca", Isimu: Revista sobre Oriente Próximo y Egipto en la Antigüedad, 10 (2007), págs. 99-114.

García-Nieto, María del Carmen; Donézar, Javier María, y López Puerta, Luis, Moderados y progresistas, 1833-1868, Madrid, Guadiana, 1971.

Gayangos, Pascual de, Escritores en prosa anteriores al siglo $X V$, Madrid, M. Rivadeneyra, 1860 (Biblioteca de Autores Españoles, 51).

Gayangos, Pascual de, La gran conquista de ultramar, que mandó escribir el rey don Alfonso el Sabio: Ilustrada con notas críticas y un glosario, Madrid, M. Rivadeneyra, 1858 (Biblioteca de Autores Españoles, 44).

Gayangos, Pascual de, Libros de caballerías, con un discurso preliminar y un catálogo razonado, Madrid, M. Rivadeneyra, 1857 (Biblioteca de Autores Españoles, 40).

Gómez Crespo, Juan, "José Amador de los Ríos en el panorama cultural del siglo XIX", Boletín de la Real Academia de Córdoba, de Ciencias, Bellas Letras y Nobles Artes, 48, 99 (1978), págs. 29-46.

Gómez Redondo, Fernando y Lucía Megías, José Manuel, "Juan Manuel”, en José Manuel Lucía Mejías y Carlos Alvar Esquerra (eds.), Diccionario filológico de literatura medieval española textos y transmisión, Madrid, Castalia, 2000. 
Gómez Redondo, Fernando, “El libro de los estados”, Monografias Aula Medieval 2 (2014) [en línea], págs. 45-66, disponible en $<\mathrm{http} / /$ parnaseo.uv.es/AulaMedieval/AulaMedieval.php?id=monografias\#monografias $>$ [Consulta: 12/05/2020].

González Mínguez, César, "Fernando IV de Castilla (1295-1312) perfil de un reinado", Espacio, tiempo y forma. Serie III, Historia medieval, 17 (2004), págs. 223-244.

Lacarra, María Jesús "Don Juan Manuel (1282-1348): orgullo nobiliario y escritura”, Monografias Aula Medieval, 2 (2014) [en línea], págs. 5-15, disponible en <http://parnaseo. uv.es/AulaMedieval/AulaMedieval.php?id=monografias\#monografias $>\quad$ [Consulta: $12 / 05 / 2020]$.

López Estrada, Francisco, "Pascual de Gayangos y la literatura medieval castellana", Alfinge: revista de filología, 4 (1986), págs. 11-29.

López García, Bernabé, "La correspondencia de José Moreno Nieto con Pascual de Gayangos”, Revista de Estudios Internacionales Mediterráneos (REIM), 2 (2007), págs. 1-19.

López Serrano, Francisco de Asís, De los orígenes a Pelayo. Modesto Lafuente en su contexto historiográfico, Málaga, Universidad de Málaga, 2013.

Manzanares de Cirre, M., "Don Pascual de Gayangos (1809-1897) y los estudios árabes", AlAndalus: revista de las escuelas de estudios árabes de Madrid y Granada, 28, 2 (1963), págs. 445-461.

Muñoz y Romero, Tomás (ed.), Colección de fueros municipales y cartas pueblas de los reinos de Castilla, León, Corona de Aragón y Navarra, Madrid, Impág. de José María Alonso, 1847.

Ocaña Vergara, José María, “Amador de los Ríos entre dos centenarios”, Boletín de la Real Academia de Córdoba, de Ciencias, Bellas Letras y Nobles Artes, 48, 99 (1978), págs. 65-93.

Pasamar Alzuria, Gonzalo y Peiró Martín, Ignacio, Diccionario Akal de historiadores españoles contemporáneos (1840-1980), Madrid, Akal, 2002.

Peiró Martín, Ignacio, "La historiografía académica en la España del siglo XIX”, Memoria y civilización: anuario de historia, 1 (1998), págs. 165-196.

Pérez Isasi, Santiago, "El nacimiento de la nación en las historias de la literatura española del siglo XIX", en Vicente Montserrat Cots y Antonio Monegal (coords.), Actas del XVII Simposio de la Sociedad Española de Literatura General y Comparada, t. I, Barcelona, Universitat Pompeu Fabra-Sociedad Española de Literatura General y Comparada, 2010, págs. 297-310.

Pérez Isasi, Santiago, "La historiografía literaria como herramienta de nacionalización en España (1833-1939)", Oihenart, 25 (2010), págs. 267-279.

Ríos, José Amador de los, Historia crítica de la literatura española, ts. I, IV, Madrid, Imprenta de don José Rodríguez, 1861-1863.

Roca y López, Pedro, "Noticia de la vida y obras de don Pascual de Gayangos. I. Juventud de Gayangos", Revista de Archivos, Bibliotecas y Museos, Tercera época, 1 (1897), págs. 544-565.

Roca y López, Pedro, "Noticia de la vida y obras de don Pascual de Gayangos. II. Gayangos en Inglaterra", Revista de Archivos, Bibliotecas y Museos, Tercera época, 2 (1898), págs. $13-32$. 
Roca y López, Pedro, "Noticia de la vida y obras de don Pascual de Gayangos (continuación)", Revista de Archivos, Bibliotecas y Museos, Tercera época, 3 (1899), págs. 101-106.

Roca y López, Pedro, Catálogo de los manuscritos que pertenecieron a D. Pascual de Gayangos existentes hoy en la Biblioteca Nacional, Madrid, Tip. de la Revista de Archivos, Bibliotecas y Museos, 1904.

Salgado Loureiro, José Ángel, "El rey molinista pensado por don Juan Manuel en El libro de los estados", História Revista, 24, 2 (2019), págs. 84-102.

Sanmartín Bastida, Rebeca, La Edad Media y su presencia en la literatura, el arte y el pensamiento españoles entre 1860 y 1890, Madrid, Universidad Complutense de Madrid, 2000.

Santamaría Torquemada, Guillermo, "La legislación en cortes sobre la cancillería de Fernando IV: 1295-1312", en Las Cortes de Castilla y León 1188-1988: actas de la tercera etapa del Congreso Cientifico sobre la Historia de las Cortes de Castilla y León, t. I, Valladolid, Simancas-Cortes de Castilla y León, 1990, pág. 285-300.

Santiño Ramírez de Alda, Santiago, "Pascual de Gayangos y Arce: una vida para la historia", Andalucía en la historia, 64 (2019), pág. 74-77.

Santiño Ramírez de Alda, Santiago, "Pascual de Gayangos. Erudición y cosmopolitismo en la España del siglo XIX", Isimu: Revista sobre Oriente Próximo y Egipto en la Antigüedad, 22 (2019), págs. 314-316.

Soto Climent, Juan, “Antonio Benavides y Fernández de Navarrete”, Diccionario Biográfico Español, Real Academia de la Historia [en línea], disponible en $<\mathrm{http} / / / \mathrm{dbe} . \mathrm{rah}$.es/biografias/13619/antonio-benavides-y-fernandez-de-navarrete> [Consulta: 30/08/2019].

Ticknor, M. Georges, Historia de la Literatura Española, vol. I, trad. de Pascual de Gayangos y Enrique de Vedia, Madrid, M. Rivadeneira, 1851.

Velasco de Castro, Rocío, “Arabismo y colonialismo español: Pascual de Gayangos y la cuestión marroquí”, Norba: Revista de Historia, 22 (2009), págs. 245-262. 
